\title{
Relationship Brand Orientation and Internal Brand Equity at Internet Service Providers: An Organization Change Readiness Effect
}

\author{
Rudy P. TOBING ${ }^{*}$, SUROSO $^{* *}$, Rizal Edy HALIM ${ }^{* * *}$, Gunawan ALIF ${ }^{* * * *}$ \\ Received: November 08, 2019 Revised: December 11, 2019 Accepted: December 18, 2019
}

\begin{abstract}
The midst competition makes a brand all together with its offering products and services is becoming a crucial element for company existence. This requires direct involvement from internal organizational to develop effective strategic branding. According to Asosiasi Penyelenggara Internet Indonesia (APJII), Indonesia's internet penetration is among the highest in Asia. The purpose of this research is to improve the strategic role of brand orientation within Internet Service Provider (ISP) for maximizing return on the company's financial and non-financial benefits by proposing organization change readiness variable. The data collection is taken using an online survey with a non-parametric sampling method and collected 68 qualified respondents for data analysis using SEM-PLS (Structural Equation Modeling with Partial Least Square). The result indicates partial hypotheses on the constructed model between variables brand orientation, brand commitment, and internal brand equity is acceptable. Another finding is stated hypotheses on organization change readiness as moderation is not accepted and means there is no significance to the constructed model. The main conclusion resumes associative human memory can shape up organization change readiness inside internal toward then brand. Relevant cues generate information received in the human brain then will create common associative and becoming social identity on internal brand equity.
\end{abstract}

Keywords: Brand Orientation, Organization Change Readiness, Internal Brand Equity, Information and Communication Technology.

JEL Classification Code: M10, M30, M31..

\section{Introduction}

Today information technology has changed the way of life in modern society. Internet access through smartphones and computers both can make consumers connect to social media, news, search engine, eCommerce and online business, cloud data storage, etc. Unlimited information

*First Author and Corresponding Author. PhD Student, Program Pascasarjana IImu Manajemen, Faculty of Economics and Business, Universitas Indonesia, Indonesia [Postal Address: JI. Pisok VIII No. 10 EB-18 Bintaro Jaya, 15220, Tangerang Selatan, Banten, Indonesia]. Email: rdtobing@yahoo.com.

**Professor, Program Pascasarjana IImu Manajemen, Faculty of Economics and Business, Universitas Indonesia. Depok, West Java. Indonesia.

***Associate Professor, Program Pascasarjana IImu Manajemen, Faculty of Economics and Business, Universitas Indonesia. Depok, West Java. Indonesia.

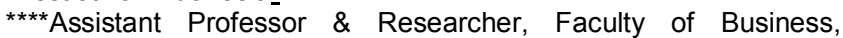
Sampoerna University, Jakarta. Indonesia..

(-) Copyright: Korean Distribution Science Association (KODISA)

This is an Open Access article distributed under the terms of the Creative Commons Attribution NonCommercial License (https:///creativecommons.org/licenses/by-nc/4.0/) which pemits unrestricted noncommercial use, distribution, and reproduction in any medium, provided the original work is properly cited. available has created massive competition among producers than before. This condition companies to seriously taking care of their brand as an important resource for long term financial sustainability. Kotler and Pfoertsch (2006) brand is a matter of delivering promises quality, originality and performance to the customer. Chernatony and Harris (2000) brand is a company asset that can't be seen but can be felt. Essentially, the business exists through the brand for satisfying consumer needs and wants, at the same time building company reputation and incremental brand valueadded toward its business is called brand equity (de Chernatony \& McDonald, 1988; Keller, 2008; Riezebos, 2003; Baumgarth \& Schmidt, 2010). Market competition has forced the modern organization to adopt change as a primary way for survival (Day, 1994).

Organization change readiness is the influence of employee belief in supporting company objectives (Armenakis, Harris, \& Mossholder, 1993). Heracleous and Barrett's (2001) belief influences employee behavior toward change and conduct the same behavior as others because of similar common value (Yaniv \& Farkas, 2005). Baller, 
Dutta, and Lanvin (2016) World Economic Forum on Networked Readiness Index or NRI shows network infrastructure readiness between countries. Network infrastructure readiness in Singapore is rating number one with a score of 6.0 the same as the previous year.

Malaysia is in rank thirty-one with score 4.9 and Indonesia is in rank seventy-three with score 4.0. Empirical shows internet service provider (ISP) plays an important role in country internet readiness. Asosiasi Penyelenggara Jasa Internet Indonesia (APJII) in 2018 penetration of internet users reach 54.68 percent from 262 million population or 171.17 million people. Internet users in Indonesia grow 10.12 percent in 2018 from last year and active users larger portion comes from age 19 to 35 years old. This is ten times compared to the growing population annually. The novelty of this research is to influence organizational change readiness to improve internal brand equity at internet service provider companies in an emerging country.

\section{Theoretical Framework}

\subsection{Brand Orientation}

Urde (1999) brand orientation is an inside-out organization approach to create, build and protect brand identity during interaction occurred with target consumers. This effort can provide a long-term brand competitive advantage. Urde (1994) brand orientation is a form of industry response toward changing consumer behavior affected by similar products and services, increase costs media marketing and a new form of media alternatives, the occurrence of market integration caused by globalization. Urde (2013) brand orientation is underlined importance brand identity likes vision, mission, and values connect with behavior in organization and culture. Urde (1994) conceptual brand orientation is the foundation of seven dimensions which is target group, corporate identity, corporate name, product, trademark, brand vision, positioning. Baumgarth, Merrilees, and Urde (2013) a limitation brand orientation study from the perspective of geography, demography, and psychograph.

Zhang, Jiang, Shabbir, and Zhu (2016) brand orientation and its dimension cannot fulfill all stakeholder's requirements due to change in the market environment, consumer requirement, time-lapse between research, etc. Keller (2003) key dimension brand knowledge is including awareness represents term of identification needs satisfaction based on brand; attribute represents feature description to identify brand name or product based on intrinsic value such as product performance, or based on extrinsic value such as brand personality or heritage; benefit represents personal value and meaning brand's product attributes to consumers; the image represents the flow of information provided to the customer either by factual or information; Thought represents personal cognitive responses to any brand information; feeling represents personal affective responses to any brand information; attitude represents overall feedback given by customer evaluations and summary judgments to any brand-related information; experience represents purchase and consumption behaviors as the result of the brand in the market. Upon justify above argumentation, therefore, the hypothesis is developed in following,

H1: Brand Orientation gives a positive influence on brand knowledge.

The brand needs to be stand up from another brand, to achieve this purpose brand need to ensure close participation in internal organizations to promote the advantage brand's product and service to customers. Activation theory is defined as an activity to encourage the customer to purchase the brand upon received brand piece of information because of proud and sense of belonging (Hoeffler \& Keller, 2003). Adopt from this terminology, each employee having a degree of emotional involvement toward the company brand based on daily interaction, and when it will be established employees' feeling proud and sense of belonging. More brand information received by the employee will create the closest attachment in employee minds. Establish a relationship between brand and employee will reflect in company personality and it creates employee trust (Celsi \& Olson, 1988; Zaichkowsky, 1985). Brand trust in an organization can promote better conditions for employees to become the brand ambassador (Leininger \& McFarland, 2002; Yaniv \& Farkas, 2005). Key brand enhancement in the company can be seen from employee daily brand involvement (Baumgarth \& Schmidt, 2010). Base on the above argumentation, therefore hypothesis is established as follow,

H2: Brand Orientation gives a positive influence on brand involvement.

Brand orientation is a combination of organizational culture and organizational behavior approaches in building organization brand relations (Burmann \& Zeplin, 2005; Burmann, Zeplin, \& Riley, 2009; Baumgarth \& Schmidt, 2010). According to Kitchen, Joanne, and Tao (2004), the company has a focus on developing relationship with employees for getting internal commitment toward brand importance for the company and how it transforms into services to the customer. Establishment internal brand plays an important role in shaping up the overall brand 
orientation in organizations and research related to brand commitment (Punjaisri \& Wilson, 2007). Organizational commitment plays an important role in determining organizational success (Hunt \& Morgan, 1995). Brand commitment arises from the internal organization and it is consumer loyalty basic measurement (Baumgarth \& Schmidt, 2010). Based on the above

hypothesis is established as follow:

H3: Brand Orientation gives positive influence to brand commitment.

\subsection{Organization Change Readiness}

The different organization presents different employee behavior and it can affect commitment to brand based on numbers of loyal consumers (Herman, 2001; Yaniv \& Farkas, 2005). Member of the organization has its unique background and behavior that could be difference when accepting change (Xu, Payne, Horner, \& Alexander, 2016). Lewin (1951); Armenakis and Harris (2002) changes at an individual level known as individual change readiness, it can influence group and organization behavior. Armenakis, Harris, and Mossholder (1993) organization change readiness has four main dimensions described as appropriateness, management support, change efficacy and personal beneficiary. Organizational changes suitable and matching with brand orientation approach which can create an impact on financial performance (Baumgarth \& Schmidt, 2010). Fugate, Kinicki, and Ashforth (2004) internal change will affect employees in the organization; however, the way employee responds it may differ between each individual based level understanding toward change. Xu, Payne, Horner, and Alexander (2016) organization is formed by a group of people who follows their knowledge and mind to follow the organization's norms, purpose and goal. Base on the above argumentation this hypothesis below proposes as follow,

H4a: Organization change readiness has moderated brand orientation and give positive influence to brand knowledge

According to Baumgarth and Schmidt (2010), brand orientation is represented internal spirit of change toward the brand. Organization change readiness requires a mindset changes starting from internal individuals, groups and organization, those all determinants are success factor to change initiatives (Armenakis, Harris, \& Mossholder, 1993; Armenakis, Harris, \& Field, 1999). Organization involvement will affect the brand success that is reflecting on its brand equity (Gromark \& Merlin, 2010). By having a clear understanding change benefit, it can create positive internal organization perspective to participate in company brand initiatives; base on the above argumentation therefore hypothesis is proposed as follow:

H4b: Organization Change Readiness has moderated Brand Orientation and give positive influence to brand involvement

Brand orientation and internal organization have linkage in terms of brand commitment and both are a complementary system for maintaining and improving organizational performance over a period of time. The brand commitment is expression toward brand sense of belonging, sense of pride toward logo, brand name and measure by the level of fanaticism in every member of the organization (Lehr \& Rice, 2002; Hult \& Ferrell, 1997; Nevis, DiBella, \& Gould, 1995; Yaniv \& Farkas, 2005). Base on above argumentation, therefore hypothesis is proposed as follow:

H4c: Organization Change Readiness has moderated Brand Orientation and give positive influence to brand commitment.

\subsection{Internal Brand Equity}

According to Aaker (1991), brand equity is integration brand entity which includes name, logo, symbol and other brand elements that may provide benefits or liability to company products and service (Kotler \& Pfoertesch, 2006). Keller (2008) three basic principles in building brand equity which is equity-based on the consumer, equity-based on company and equity-based on financial. Equity based consumer is a principle related to consumer's perceive producer's communication on informing and offering product and service, media campaigns, and others. Equity based company principle is related to the company's perspective in providing its product and service, including the use of advertising and other promotional activities to inform quicker product availability, shorter product distribution, etc. Equity based financial principle relates to the company's perspective in finance, where the brand is an asset similar to plant and equipment is all used to deliver product and service (Hoeffler \& Keller, 2003). Aaker (1991) brand equity dimension consists of brand loyalty, brand awareness, brand association, and perceived quality.

The associative network model is derived from human associative memory theory; it is the primary platform brand knowledge development (Franzen \& Bouwman, 2002; Love $\&$ Singh, 2011). More customers aware of the brand, it means customer has better knowledge and ability to encoding a better way to develop knowledge procedures (Hoeffler \& Keller, 2003). Brand knowledge relates to cognitive visualization of the brand and it will result in 
brand loyalty establishment within the organization (Keller, 2003). A stronger brand is usually developed better structure consumer knowledge that is closely connecting with specific brand associations (Reichheld, 1996; Baumgarth, 2010). Papasolomou and Vrontis (2006) high brand equity has a close relationship with a stronger brand. Brand equity is an indicator of brand market share position. Base on the above argumentation, therefore hypothesis is proposed as follow:

H5: Brand knowledge has a positive influence on internal brand equity

According to Zaichowsky (1985), brand involvement is an important concept to examine individual motivation toward the company brand. Besides, involvement is a motivational degree to understand consumer attitudes towards products or brands (Guthrie \& Kim, 2009); under the same analogy, this conceptual extends employee brand attitudes and how internal organization leveling trust in the brand. Involvement defines as degree or intensity of interest to certain brand or products and services (Park \& Young, 1983). Jin (2016) brand equity is an important concept of brand management to get market competitiveness through a strong brand. Keller $(1993,2008)$ and Aaker (1991) brand equity can create positive brand equity in the customer mind and contributes to company benefit.

According to Keller (1993), ongoing benefit is included financial gain, generating higher margin profit, better selling price, brand development, effective brand communication and higher preference to do purchase products and services. Baumgarth and Schmidt (2010) internal brand equity is an effect of strengthening employee behavior toward brand identity, image, and reputation. Base on the above argumentation therefore below hypothesis is proposed,

H 6: Brand involvement has a positive influence on internal brand equity

The organization that is consistently ready facing change can be seen from their implementation commitment over a period of time and characterize as a competitive organization (Balogun \& Hope, 2008; Baumgarth, 2010); this becomes organization different from most organization in general (By, 2005; Meaney \& Pung, 2008). Brand commitment is defined as an individual psychological attachment to the brand through a consistent exchange brand point of view and preserved a better level to achieve brand image (Baumgarth \& Schmidt, 2010). Base on the above argumentation, therefore, hypothesis is proposed as follow,

H 7: Brand commitment has a positive influence on internal brand equity

Following hypothesis constructs in Figure.1 explain the theoretical framework shown as follow:

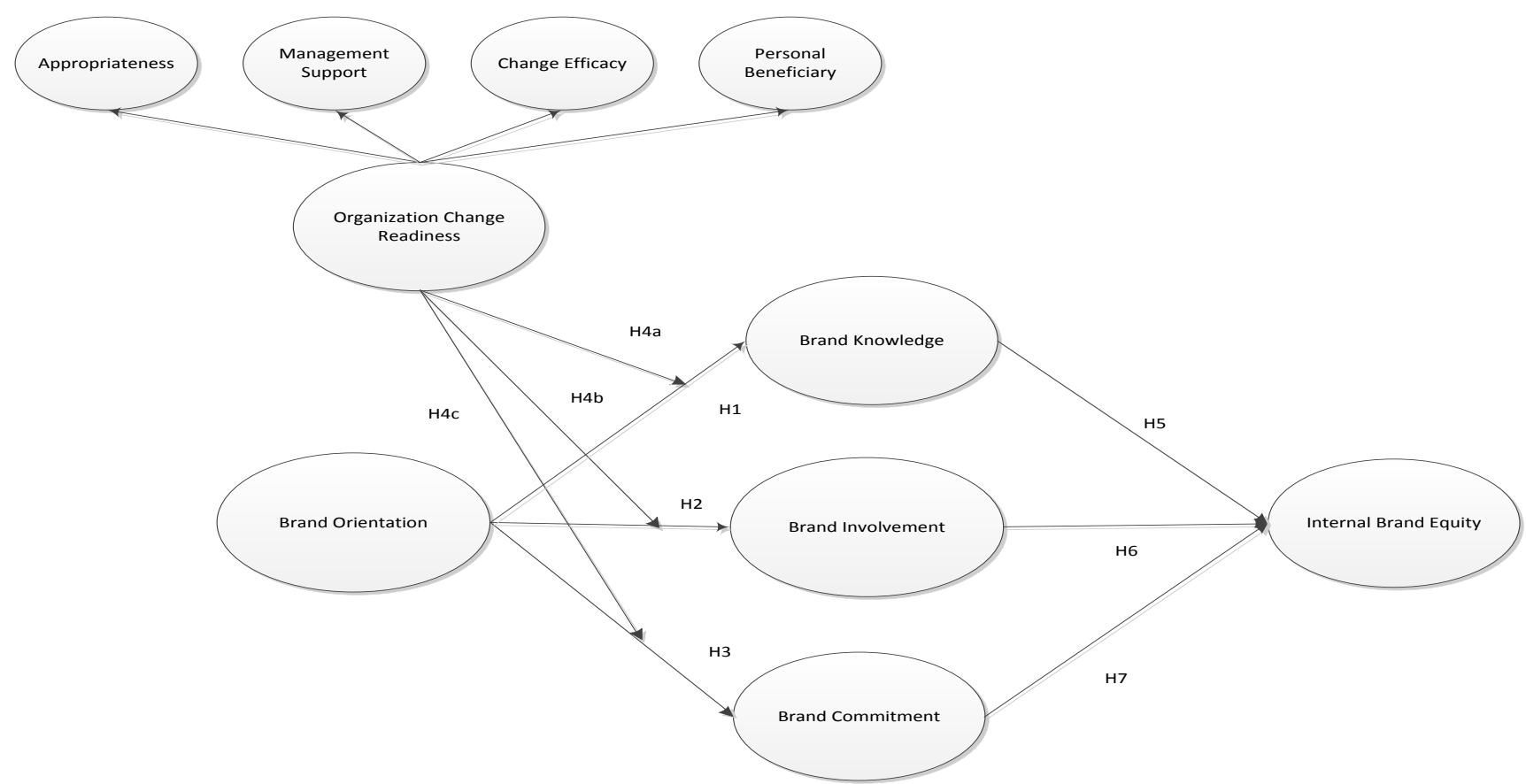

Figure 1: The constructed model 


\section{Research Method}

This research is conducted to answer the relationship between model and its indicators and it should be done through statistical analysis that relies on data collection for data processing analysis (Sekaran, 2010; Maholtra, 2007). Non-probability sampling is used in a group of population from internet service provider members of Asosiasi Penyelenggara Jasa Internet Indonesia (APJII) and their customers with a method of purposive sampling based on judgment criteria (Churchill \& Iacobucci, 2005). Business to Business (B2B) respondents represented brand decisionmakers at ISP companies such as assistant manager, manager, GM, director, president, and CEO.

The answer forms in a six-point Likert scale with accompanied definition i.e. value $1=$ for strongly disagree, until value $6=$ for strongly agree. The questionnaire is formatted in Google Forms for online simplification and upon survey is completed immediately transfer to Microsoft Excel format. The association is sending the survey e-mail to 400 registered members at the secretariat office of APJII. The return online survey from 74 respondents and screening with control question; then is selected, 68 valid respondents. Ringle, Wende, and Will (2005); Hair, Hult, Ringle, and Sarstedt (2014) PLS was introduced in 1966 by Herman Wold, it has used ever seen to explain variance effect independent variables related with construct model and work robustly in small sample size, non-normal distribution and undeveloped theory. Besides, PLS can estimate models within a large number of latent variables and indicators and even with a small sample size (Chin, Peterson, \& Brown, 2008; Henseler, Ringle, \& Sinkovics, 2009).

Table 1: Characteristic of respondent

\begin{tabular}{|c|c|c|c|c|c|}
\hline \multicolumn{6}{|c|}{ Internet service providers (ISP) } \\
\hline Respondent Profile & Frequency & Percentage & Respondent Profile & Frequency & Percentage \\
\hline \multicolumn{3}{|c|}{ Gender } & \multicolumn{3}{|c|}{ Position } \\
\hline Male & 56 & $82 \%$ & Assistant Manager & 4 & $6 \%$ \\
\hline \multirow[t]{2}{*}{ Female } & 12 & $18 \%$ & Manager & 34 & $50 \%$ \\
\hline & & & GM & 4 & $6 \%$ \\
\hline \multicolumn{3}{|c|}{ Age Bracket } & Vice President & 1 & $1 \%$ \\
\hline$<25$ year old & 3 & $4 \%$ & Director & 20 & $29 \%$ \\
\hline $25-30$ year old & 15 & $22 \%$ & President / CEO & 5 & $7 \%$ \\
\hline $31-35$ year old & 14 & $21 \%$ & & & \\
\hline $36-40$ year old & 12 & $18 \%$ & \multicolumn{3}{|c|}{ Education } \\
\hline $41-45$ year old & 10 & $15 \%$ & Senior High School & 3 & $4 \%$ \\
\hline $46-50$ year old & 12 & $18 \%$ & Diploma (D1 - D3) & 2 & $3 \%$ \\
\hline \multirow[t]{2}{*}{$>51$ year old } & 2 & $3 \%$ & Bachelor (S1) & 32 & $47 \%$ \\
\hline & & & Master Degree (S2) & 29 & $43 \%$ \\
\hline \multicolumn{3}{|c|}{ Employment with Company } & Doctoral Degree (S3) & 2 & $3 \%$ \\
\hline $0-4$ year & 30 & $44 \%$ & & & \\
\hline $5-10$ year & 20 & $29 \%$ & \multicolumn{3}{|c|}{ Responsibility on Brand } \\
\hline $11-15$ year & 11 & $16 \%$ & $0-4$ year & 39 & $57 \%$ \\
\hline $16-20$ year & 5 & $7 \%$ & $5-10$ year & 23 & $34 \%$ \\
\hline \multirow[t]{7}{*}{$21>$ year } & 2 & $3 \%$ & $11-15$ year & 3 & $4 \%$ \\
\hline & & & $>15$ tahun & 3 & $4 \%$ \\
\hline & & & \multicolumn{3}{|c|}{ Department } \\
\hline & & & Head office & 26 & $38 \%$ \\
\hline & & & Marketing \& Sales & 35 & $51 \%$ \\
\hline & & & Brand \& Product Manager & 4 & $6 \%$ \\
\hline & & & IT \& Operation support & 3 & $4 \%$ \\
\hline
\end{tabular}

Another PLS advantage is the software ability to conduct a simultaneous test and structural model and combined regression and component factor analysis (CFA). Hair, Hult, Ringle, and Sarstedt (2014) sample size criteria setting according to Barclay, Higgins and Thompson in 1995, "it should fit criteria 10 times of the largest formative indicator use in a single construct OR 10 times of the largest number of structural path directed to a particular construct in the structural model". The criteria represent the largest number of structural paths that directed to one latent 
variable; which this research represents construct 3 paths multiple 10 times equal to 30 respondents. The data collection process is conducted in the first week of April 2018 until the fourth week of Sept 2018. Upon completing data tabulation, the 68 respondents ready to be analyzed. Table.1. below shows the classification characteristic of the respondents.

\section{Results}

\subsection{Descriptive Analysis}

Respondents gender are classified by male $=82 \%$ and female $=18 \%$, majority respondents come from groups age between $25-50$ years old $=93 \%$ which majority respondent represents the age of the productive worker. Education background is majority bachelor degree $=47 \%$ and master degree $=43 \%$. Employment time with company between $0-4$ years $=44 \%, 5-10$ years $=29 \%$ and $11-15$ years $=16 \%$. Brand responsibility to company is between $0-4$ years $=57 \%$ and $5-10$ years $=34 \%$. Further finding on the functional department related to brand implementation is majority come from the marketing \& sales department $51 \%$ and head office $38 \%$.

\subsection{Measurement Evaluation}

This study is using partial least square (PLS) SmartPLS 3.2.8 to estimate validity and reliability measurement indicator and construct a model by observing the path model, inner model, and outer model. The inner model specifies observed interaction between latent variables; whereas the outer model specifies observing an interaction between latent variables and its observed variables (Henseler, Ringle, \& Sinkovics, 2009). Non-parametric sampling with bootstrapping 5000 replication to obtain standard errors of estimates use on this analysis.

Hair, Hult, Ringle, and Sarstedt (2014) test is conducted for checking internal consistency, convergent validity, and discriminant validity. This is included factor loadings, Cronbach's alpha $(\alpha)$ or composite reliabilities $(\rho c)$ and average variance extracted (AVE). The minimum coefficient value for loading indicators should equal or above 0.6, composite reliability ( $\rho c$ ) should equal or above 0.7 , Cronbach's Alpha $(\alpha)$ should equal or above 0.6 and average variance extracted (AVE) should equal or above 0.5 value. Convergent validity is conducted to ensure all items loading in indicators have a value equal at least or much higher from their corresponding constructs compare to other constructs. Discriminant validity is conducted by testing the Fornell Larcker criterion and cross-loadings.

Hypothesis test measurement uses T-Test with a confident interval of $5 \%$ (2-tail) or T-table $>1.96$ with assumption at normal condition (Hair, Hult, Ringle, \& Sarstedt, 2014). Greater T- statistic scores compare critical Z score indicated a positive relationship between construct variables and hypothesis is accepted. The opposite result is applied another way around.

\subsection{Outer Model Evaluation}

Outer model evaluation is a reflective relationship latent variable and indicators measurement model by checking its validity and reliability. The validity outer model covers factor loading indicators, convergent validity, and discriminant validity. PLS algorithm construct model and indicators represent factor loadings brand orientation, brand knowledge, brand involvement, brand commitment, appropriateness, change efficacy, management support, and personal beneficiary; all have a score above 0.60 . Hair, Hult, Ringle, and Sarstedt (2014) factor loadings to be valid should have scored equal to 0.60 or above. Table. 2 all construct items and their indicators are valid and shown below, Convergent validity views construct measures and checking positive correlation with alternative measures (Hair, Hult, Ringle, \& Sarstedt, 2014).

Process analysis involves measurement composite reliabilities ( $\rho c)$, Cronbach's Alpha $(\alpha)$ and average variance extracted or AVE. Hair, Hult, Ringle, and Sarstedt (2014); Henseler, Ringle, and Sinkovics (2009) convergent validity measurement has a better preference to use composite reliability $(\rho c)$ instead of Cronbach's Alpha $(\alpha)$. Composite reliability $(\rho c)$ is measured internal consistency reliability to test unidimensional loading indicators and its score should be equal or above $=0.70$ to be valid or internal consistency reliability is accepted (Nunnally \& Bernstein 1994; Henseler, Ringle, \& Sinkovics, 2009).

A value below $=0.6$ indicates a lack of reliability (Henseler, Ringle, \& Sinkovics, 2009). Higher value composite reliability more reliable than the constructed model will be. Table.2. result composite reliability $(\rho c)$ indicates brand commitment $=0.894$, brand knowledge $=$ 0.886 , brand orientation $=0.816$, internal brand equity $=$ 0.923 and organization change readiness construct variables which are appropriateness $=0.921$, change efficacy $=0.881$, management support $=0.887$ and personal beneficiary $=$ 0.942 . Composite reliability ( $\rho c)$ result indicators all above $=0.80$; which means reliability is satisfactory and there is no unidimensional in construct model.

Another measurement to test convergent validity is using Cronbach's Alpha ( $\alpha$ ) where value should be equal or above $=0.6$ in order to be valid; PLS Algorithm on the construct shows in Table. 2 values of brand commitment $=0.859$, brand knowledge $=0.828$, internal brand equity $=0.904$ and variable organization change readiness which is 
appropriateness $=0.893$, change efficacy $=0.819$, management support $=0.832$, personal beneficiary $=0.908$, brand orientation $=0.658$ and brand involvement $=0.649$. The values are above $=0.60$ meaning variables construct model is valid.

Average Variance Extracted (AVE) is sufficient convergent validity where indicator latent variable more than half variance its indicators on an average basis (Götz, Liehr-Gobbers, \& Krafft, 2009; Henseler, Ringle, \& Sinkovics, 2009). Table. 2 shows AVE has result brand commitment $=0.584$, brand knowledge $=0.574$, brand orientation $=0.599$, internal brand equity $=0.632$ and organization change readiness variables of appropriateness $=0.700$, change efficacy $=0.650$, management support $=$ 0.664 and personal beneficiary $=0.845$. Hair, Hult, Ringle, and Sarstedt (2014) validity is comparing AVE value square root with latent variable correlations and AVE construct have to be greater than its highest correlation on any other construct; the value should above 0.60 .

Table 2: Convergent validity measurement model

\begin{tabular}{|c|c|c|c|c|c|}
\hline Construct & Indicator & Factor Loadings & Cronbach Alpha ( $\alpha$ ) & Composite Reliability ( $\rho c)$ & AVE \\
\hline \multirow{6}{*}{$\begin{array}{c}\text { Brand } \\
\text { Commitment }\end{array}$} & $\mathrm{BC} 1$ & 0.706 & \multirow{6}{*}{0.859} & \multirow{6}{*}{0.894} & \multirow{6}{*}{0.586} \\
\hline & $\mathrm{BC} 2$ & 0.816 & & & \\
\hline & $\mathrm{BC} 3$ & 0.800 & & & \\
\hline & $\mathrm{BC} 4$ & 0.707 & & & \\
\hline & BC6 & 0.788 & & & \\
\hline & $\mathrm{BC} 7$ & 0.769 & & & \\
\hline \multirow{3}{*}{$\begin{array}{c}\text { Brand } \\
\text { Involvement }\end{array}$} & BI1 & 0.800 & \multirow{3}{*}{0.649} & \multirow{3}{*}{0.801} & \multirow{3}{*}{0.574} \\
\hline & $\mathrm{BI} 3$ & 0.697 & & & \\
\hline & BI5 & 0.773 & & & \\
\hline \multirow{4}{*}{$\begin{array}{c}\text { Brand } \\
\text { Knoweldge }\end{array}$} & BK1 & 0.821 & \multirow{4}{*}{0.828} & \multirow{4}{*}{0.886} & \multirow{4}{*}{0.661} \\
\hline & BK2 & 0.835 & & & \\
\hline & BK3 & 0.839 & & & \\
\hline & BK5 & 0.753 & & & \\
\hline \multirow{3}{*}{ Brand Orientation } & $\mathrm{BO} 1$ & 0.656 & \multirow{3}{*}{0.658} & \multirow{3}{*}{0.816} & \multirow{3}{*}{0.599} \\
\hline & $\mathrm{BO} 3$ & 0.851 & & & \\
\hline & BO4 & 0.801 & & & \\
\hline \multirow{7}{*}{$\begin{array}{c}\text { Internal Brand } \\
\text { Equity }\end{array}$} & IBE10 & 0.784 & \multirow{7}{*}{0.904} & \multirow{7}{*}{0.923} & \multirow{7}{*}{0.632} \\
\hline & IBE13 & 0.743 & & & \\
\hline & IBE14 & 0.783 & & & \\
\hline & IBE6 & 0.853 & & & \\
\hline & IBE7 & 0.857 & & & \\
\hline & IBE8 & 0.797 & & & \\
\hline & IBE9 & 0.757 & & & \\
\hline \multirow{5}{*}{ Appropriateness } & OCRA1 & 0.834 & \multirow{5}{*}{0.893} & \multirow{5}{*}{0.921} & \multirow{5}{*}{0.700} \\
\hline & OCRA3 & 0.823 & & & \\
\hline & OCRA4 & 0.738 & & & \\
\hline & OCRA5 & 0.865 & & & \\
\hline & OCRA6 & 0.813 & & & \\
\hline \multirow{4}{*}{ Change Efficacy } & OCRC3 & 0.738 & \multirow{4}{*}{0.819} & & \\
\hline & OCRC4 & 0.862 & & 0001 & 0650 \\
\hline & OCRC5 & 0.784 & & 0.881 & 0.650 \\
\hline & OCRC6 & 0.835 & & & \\
\hline & OCRM1 & 0.87 & & & \\
\hline & OCRM2 & 0.793 & 0832 & 0887 & \\
\hline $\begin{array}{l}\text { Management } \\
\text { Sunport }\end{array}$ & OCRM4 & 0.847 & 0.832 & 0.887 & 0.664 \\
\hline & OCRM6 & 0.743 & & & \\
\hline & OCRP1 & 0.904 & & & \\
\hline Personal & OCRP2 & 0.911 & 0.908 & 0.942 & 0.845 \\
\hline Beneficiary & OCRP3 & 0.942 & & & \\
\hline
\end{tabular}

Discriminant validity is measuring correlation at construct truly distinct from other constructs and indicators represent in a single construct (Hair, Hult, Ringle, \& Sarstedt, 2014). Henseler, Ringle, and Sinkovics (2009) cross-loadings and Fornell-Larcker criterion analyses use to assess discriminant validity. Hair, Hult, Ringle, and
Sarstedt (2014) cross-loadings is a measurement of indicator correlation with other constructs in the model. Indicator loading should have a higher value than other loadings value; acceptable value cross-loadings should be equal or above 0.60 (Chin, 1998; Götz, Liehr-Gobbers, \& Krafft, 2009; Henseler, Ringle, \& Sinkovics, 2009). 
Result cross-loadings brand orientation and indicators have score $=0.655$ to 0.851 , cross-loadings brand commitment and indicators has score $=0.706$ to 0.817 , cross-loadings brand involvement and indicators has score $=0.697$ to 0.800 , cross-loadings brand knowledge and indicators has score $=0.754$ to 0.839 , cross-loadings internal brand equity and indicators has score $=0.743$ to 0.857 , cross-loadings appropriateness and indicators has score $=0.813$ to 0.865 , cross-loadings change efficacy and indicators has score $=0.738$ to 0.862 , cross-loadings management support and indicators has score $=0.743$ to 0.870 , cross-loadings personal beneficiary and indicators has score $=0.904$ to 0.942 ; means construct variables and indicators are proved distinctly different between one to another construct model.

Fornell Larcker criterion is discriminant validity to check the latent variable and assigned indicators to share more variance rather than another latent variable (Henseler, Ringle, \& Sinkovics, 2009). Fornell-Larcker criterion measures construct variable and cross-loadings at indicators level combined all together can produce sufficient difference and non-unidimensional. Good discriminant validity applies when correlation within the constructed variable has a higher value compared to another construct variable. Table.3. Fornell-Larcker criterion shows correlation each construct variable generates higher value internally compare to other constructs model.

Table 3: Fornell-Larcker Criterion

\begin{tabular}{|c|c|c|c|c|c|c|c|c|c|}
\hline & Appropriateness & $\begin{array}{c}\text { Brand } \\
\text { Commitment }\end{array}$ & $\begin{array}{c}\text { Brand } \\
\text { Involvement }\end{array}$ & $\begin{array}{c}\text { Brand } \\
\text { Knowledge }\end{array}$ & $\begin{array}{c}\text { Brand } \\
\text { Orientation }\end{array}$ & $\begin{array}{l}\text { Change } \\
\text { Efficacy }\end{array}$ & $\begin{array}{c}\text { Internal } \\
\text { Brand } \\
\text { Equity }\end{array}$ & $\begin{array}{l}\text { Management } \\
\text { Support }\end{array}$ & $\begin{array}{c}\text { Personal } \\
\text { Beneficiary }\end{array}$ \\
\hline Appropriateness & 0.836 & & & & & & & & \\
\hline $\begin{array}{c}\text { Brand } \\
\text { Commitment }\end{array}$ & 0.405 & 0.766 & & & & & & & \\
\hline $\begin{array}{c}\text { Brand } \\
\text { Involvement }\end{array}$ & 0.217 & 0.410 & 0.758 & & & & & & \\
\hline $\begin{array}{c}\text { Brand } \\
\text { Knowledge }\end{array}$ & 0.272 & 0.473 & 0.322 & 0.813 & & & & & \\
\hline $\begin{array}{c}\text { Brand } \\
\text { Orientation }\end{array}$ & 0.361 & 0.552 & 0.526 & 0.533 & 0.774 & & & & \\
\hline $\begin{array}{l}\text { Change } \\
\text { Efficacy }\end{array}$ & 0.471 & 0.185 & 0.038 & 0.328 & 0.050 & 0.806 & & & \\
\hline $\begin{array}{l}\text { Internal Brand } \\
\text { Equity }\end{array}$ & 0.463 & 0.405 & 0.296 & 0.284 & 0.291 & 0.439 & 0.795 & & \\
\hline $\begin{array}{l}\text { Management } \\
\text { Support }\end{array}$ & 0.574 & 0.467 & 0.293 & 0.341 & 0.341 & 0.551 & 0.541 & 0.815 & \\
\hline $\begin{array}{c}\text { Personal } \\
\text { Beneficiary }\end{array}$ & 0.330 & 0.332 & 0.171 & 0.039 & 0.156 & 0.099 & 0.217 & 0.312 & 0.919 \\
\hline
\end{tabular}

\subsection{Inner Model Evaluation}

Inner model evaluation is predictive accuracy measurement by calculating the squared correlation between specific endogen latent variable actual and predicted values (Hair, Hult, Ringle, \& Sarstedt, 2014). R square or $\mathrm{R}^{2}$ is used to evaluate coefficient determinant where higher $\mathrm{R}^{2}$ values represents stronger direct influence exogen variable toward endogen variable. Value $R^{2}$ guidance is range from 0 to 1 , where higher value indicates higher level predictive accuracy; group fall into score $0.75,0.50$ and 0.25 has meaning as substantial, moderate and weak; however, it is difficult to set standard acceptance $\mathrm{R}^{2}$ values because model complexity and type of research discipline (Hair, Ringle, \& Sarstedt, 2011; Henseler, Ringle, \& Sinkovics, 2009; Hair, Hult, Ringle, \& Sarstedt, 2014).

$\mathrm{R}$ Square or $\mathrm{R}^{2}$ explain score relationship between each construct variable brand orientation and moderation organization change readiness score $=34.4 \%$ has moderate influence; brand involvement and moderation organization change readiness score $=29.1 \%$ has moderate influence; brand commitment and moderation organization change readiness score $=40.1 \%$ has moderate influence. Construct variables brand knowledge, brand involvement, and brand commitment score $=19.1 \%$ have weak influence. Hair, Hult, Ringle, and Sarstedt (2014) hypotheses are valid when T-test above score 1.96 (2-tail) T-test and accepting H0 (null hypothesis). In Table. 4 result shows hypotheses T-test 1,2, 3 and 7 are accepted.

Figure.2. Finding in brand orientation constructs is proved significant by coefficient result brand orientation to brand knowledge $=4.063$, brand orientation to brand involvement $=4.050$ and brand orientation to brand commitment $=4.275$, is above 1.96 and $\mathrm{H} 0$ (null hypotheses) is accepted. Result status on organization change readiness relationship with dimension appropriateness $=21.376$, relations with management support $=6.647$, relations with change efficacy $=16.084$ and relations with personal beneficiary $=4.491$; with 
measures coefficient above $=1.96$ are significant and $\mathrm{H} 0$ (null hypotheses) is accepted.

The relationship between organizational change readiness to brand involvement $=1.544$ and brand knowledge $=0.586$, in Figure. 2 shows in-significant results below 1.96 therefore $\mathrm{H} 0$ is rejected. The relationship between organizational change readiness to brand commitment shows significant results $=3.618$ and above 1.96; therefore, $\mathrm{H0}$ is accepted. In other words, good condition organization change readiness can produce good condition brand commitment. Moderation effect number 1, 2 or 3 is not significant to construct the model. The analysis finds out hypotheses $4 \mathrm{a}, 4 \mathrm{~b}, 4 \mathrm{c}, 5$ and 6 is rejected because all T-test score is below 1.96 .

Table 4: Total Effect, Mean, STDEV, T-Values, P-Values

\begin{tabular}{|c|c|c|c|c|c|c|}
\hline \multicolumn{2}{|l|}{ Hypothesis } & \multirow{2}{*}{$\begin{array}{c}\begin{array}{c}\text { Original } \\
\text { Sample (O) }\end{array} \\
0.302\end{array}$} & \multirow{2}{*}{$\begin{array}{c}\begin{array}{c}\text { Sample } \\
\text { Mean (M) }\end{array} \\
0.300\end{array}$} & \multirow{2}{*}{$\begin{array}{c}\begin{array}{c}\text { Standard } \\
\text { Deviation } \\
\text { (STDEV) }\end{array} \\
0.1139 \\
\end{array}$} & \multirow{2}{*}{$\begin{array}{c}\begin{array}{c}\text { T Statistics } \\
(|\mathbf{O} / \mathbf{S T D E V}|)\end{array} \\
2.175\end{array}$} & \multirow{2}{*}{$\begin{array}{c}\text { Hypothesis result } \\
\text { Significant }\end{array}$} \\
\hline $\begin{array}{l}\text { Brand Commitment } \\
\text {-> Internal Brand Equity }\end{array}$ & H7 & & & & & \\
\hline $\begin{array}{c}\text { Brand Involvement } \\
\text {-> Internal Brand Equity }\end{array}$ & H6 & 0.141 & 0.179 & 0.162 & 0.872 & Not Significant \\
\hline $\begin{array}{c}\text { Brand Knowledge } \\
->\text { Internal Brand Equity }\end{array}$ & H5 & 0.096 & 0.086 & 0.211 & 0.454 & Not Significant \\
\hline $\begin{array}{c}\text { Brand Orientation } \\
->\text { Brand Commitment }\end{array}$ & $\mathrm{H} 1$ & 0.441 & 0.434 & 0.103 & 4.275 & Significant \\
\hline $\begin{array}{l}\text { Brand Orientation } \\
->\text { Brand Involvement }\end{array}$ & $\mathrm{H} 2$ & 0.501 & 0.509 & 0.124 & 4.050 & Significant \\
\hline $\begin{array}{c}\text { Brand Orientation } \\
->\text { Brand Knowledge }\end{array}$ & $\mathrm{H} 3$ & 0.473 & 0.473 & 0.116 & 4.063 & Significant \\
\hline $\begin{array}{l}\text { Moderating Effect } 1 \\
->\text { Brand Knowledge }\end{array}$ & $\mathrm{H} 4 \mathrm{a}$ & 0.169 & 0.167 & 0.131 & 1.292 & Not Significant \\
\hline $\begin{array}{l}\text { Moderating Effect } 2 \\
->\text { Brand Involvement }\end{array}$ & $\mathrm{H} 4 \mathrm{~b}$ & 0.092 & 0.086 & 0.128 & 0.721 & Not Significant \\
\hline $\begin{array}{l}\text { Moderating Effect } 3 \\
\text {-> Brand Commitment }\end{array}$ & $\mathrm{H} 4 \mathrm{c}$ & -0.056 & -0.054 & 0.093 & 0.602 & Not Significant \\
\hline
\end{tabular}

Figure 2 hypotheses testing is concluded construct model on brand orientation, brand commitment, moderation organization change readiness and internal brand equity show direct effect.

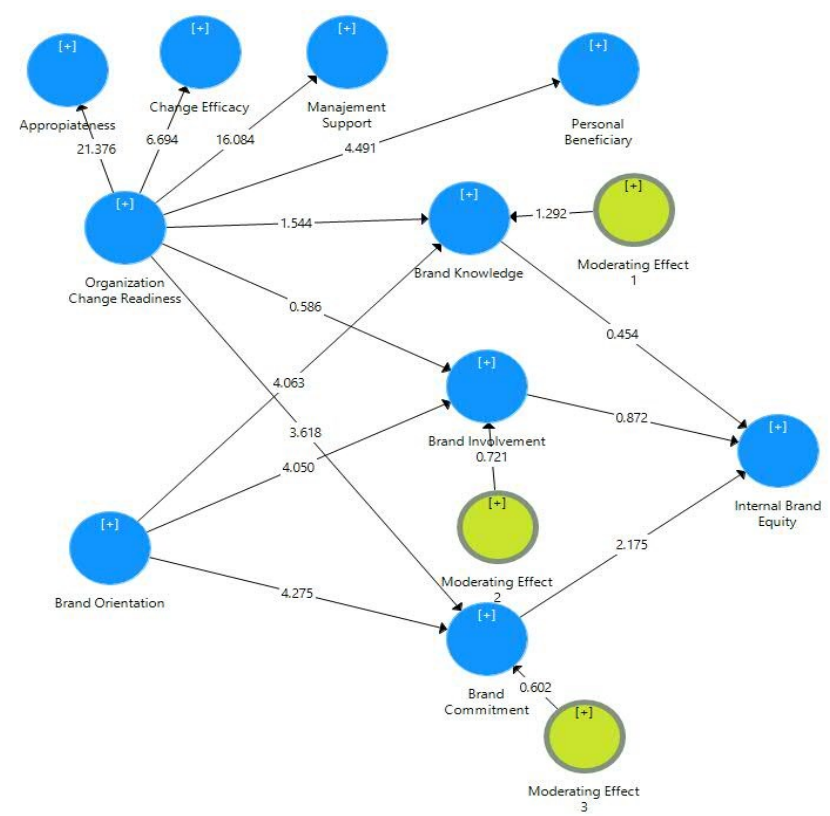

Figure 2: Path Model: T-Test Hypothesis testing

\section{Discussion}

Research finding explanation results from the latent variable in the constructed model and results from moderation organization change readiness in the constructed model. The first explains direct relationship brand orientation, brand commitment, internal brand equity and moderation organization change readiness. Brand orientation provides differentiation on products and services from another competitor by strengthening employees' perspective on company brand (Urde, 1994; Baumgarth \& Schmidt, 2010). The brand has three basic principles in setting up internal brand equity inside the organization which is equity-based on the consumer, equity-based on financial and equity-based on the company for achieving a stronger brand (Keller, 2009).

Similarly, the marketing role is created product and service differentiation with also building company reputation in the customer's mind. This fundamental thinking is depended on consumer involvement in any selected incoming information to be stored in brain memory. Establish a strong brand is required sufficient brand knowledge in internal organization and creates company brand association (Reichheld, 1996; Baumgarth \& Schmidt, 2010). A brand is intangible and needs an association with 
sensible features so the brand can easily be recognized by the consumer (Keller, 2003; Love \& Singh, 2011). The associative network model is primary platform brand knowledge development.

Franzen and Bouwman (2002) associative networks model, derives from the human associative memory theory of neuroscientific, is defined as incorporated more than one cognitive principle association key feature human memory. Wherein practice represents key features information going to parallel processes in the human brain and simultaneously converging all multiple connections surpass all connecting pathways inside the brain and trigger associative activation, such as key features information of hamburger, french fries, and coca-cola then it will be simultaneously triggered image of McDonald's. Individual brand decision-making preferences follow brain memory and this is referring to brand associative (Aaker, 1991).

The second is to explain not significance moderation organization change readiness in the constructed model. In Asia's emerging country is a common practice each behavior should equally produce identity same with group identity to get acknowledged by society and it becomes society identity. This result explains this study may produce non-significant moderation organization change readiness results in an emerging country. Meaney and Pung (2008) lack of organization change readiness is identical to the status quo organization and only comfort to stay in the comfort zone. Social identity is categorized based on psychological and sociological explaining organization categorization, identification and group behavior (Tajfel \& Turner, 1986; ANU, 2006; Love \& Singh, 2011). Building an organization commitment toward a brand can make employees a loyal member of the organization and reinforce brand promises (Backhaus \& Tikoo, 2004).

Schein and Bennis (1965), Walinga (2008) readiness is key to organizational change; it closes to internal organization interest (Armenakis \& Harris, 2002; Walinga, 2008). Organization change readiness is management direction to do continuing organization process improvement, building capabilities and response to internal and customer (Moran \& Brightman, 2001; By, 2005). Change is an embedded organization strategic and operational; the future organization needs to identify strategic change between now and future (Burnes, 2004; Rieley \& Clarkson, 2001; By, 2005). Human associative memory is an individual brain reaction based on relevant contextual nodes that fulfill personal preference and relates group organization change readiness (Franzen \& Bouwman, 2002; Love \& Singh, 2011). Successful organization change readiness implementation depends on management involvement in the process and employee able to fulfill all change procedures (By, 2005). Empirical evidence shows change is inevitable; the company needs to prepare internal readiness for organizational survival (Burnes, 2004; De Wit \& Meyer, 2005; Luecke, 2003; Nelson, 2003: By, 2005).

The managerial implication in this study is associative network model implementation in an emerging country like Indonesia to give brand equity value at ISP company. Respondent of this study is entrepreneur and association members. business to business (B2B) revenue comes from pricing project tender. and in emerging countries price is playing a crucial element to win a project. This is reversely from brand intention which is providing intangible valueadded. Rajgopal, Venkatachalam and Kotha (2002); Hunt and Madhavaram (2012) empirical facts indicate the right management decision in internet companies has positive implications for company financial performance. This is in line with APJII objectives-to do organizational mindset transformation from transactional-based to value-based approaches.

Research limitation for future study is expanding research to another sector in information and communication technology (ICT) in Indonesia and another emerging country. Further study in the associative network model relates to moderation organization change readiness for internal brand equity improvement is also recommended for deeper insight on brand equity development.

\section{Conclusion}

This study concludes the direct relationship established between brand commitment, moderating organization change readiness and internal brand equity at internet service providers (ISP) in the emerging country. There is a different level adoption of organization change readiness in an emerging country and developing country. Associative network model can be medium to enhance organizational change readiness acceptance toward brand orientation. Finally, this study highlights influence organization change readiness in supporting internal brand equity for business sustainability at an emerging country in Asia.

\section{References}

Aaker, D. A. (1991), Managing Brand Equity. New York, NY: Free Press.

Australian National University (ANU). (2006). Social identity theory and social-categorization theory. Retrieved August 11, 2019, from http://Psychology. anu.edu.au/groups/categorisation/socialidentity.php.

Armenakis, A. A., Harris, S., \& Mossholder, K. W (1993). Creating Readiness for Organizational Change. Human Relations, 46(6), 681-704. doi: $10.1177 / 001872679304600601$ 
Armenakis, A. A., Harris, S. G., \& Field, H.S. (1999). Making Change Permanent: A Model for institutionalizing change interventions. Research in Organizational Change and Development, 12, 97- 128. https://doi.org/10.1016/S0897-3016(99)12005-6

Armenakis, A, A., \& Harris, S. G. (2002). Crafting a change message to create transformational Readiness. Journal of Organizational Change Management, 15(2), 169183. http://dx.doi.org/10.1108/09534810210423080

Backhaus, K., \& Tikoo, S. (2004). Conceptualizing and researching employer branding. Career Development International, 9(5), 501-517.

Balogun, J., \& Hailey, V. H. (2008). Exploring strategic change. Upper Saddle River, NJ: Pearson Education. https://doi.org/10.1007/s13398-014-0173-7.2

Baller, S; Dutta, S., \& Lanvin, B. (2016). The Global Technology Report 2016. World Econonmic Forum. Geneva.. Retrieved 10 August 2019, from http://www3.weforum.org/docs/GITR2016/WEF_GITR Full_Report.pdf

Barclay, D., Higgins, C., \& Thompson, R. (1995). The partial least square (PLS) approach to causing modeling; personal computer adoption and use an illustration. Technology Studies, 2(2), 285-309. Retrieved from http://refhub.elsevier.com/S0969-6989(19)302036/sref17

Baumgarth, C., \& Schmidt, M. (2010). How strong is the business-to-business brand in the workforce? An empirically-tested model of "internal brand equity" in a business-to-business setting. Industrial Marketing Management, 39(8), 1250-1260. https://doi.org/10.1016/j.indmarman.2010.02.022

Baumgarth, C., Merrilees, B., \& Urde, M. (2013) Brand orientation: Past, present, and future. Journal of Marketing Management, 29(9-10), 973-980. doi: 10.1080/0267257X.2013.817768

Burnes, B. (2004). Managing Change: A Strategic Approach to Organisational Dynamics, $\left(4^{\text {th }} \mathrm{ed}\right)$. Harlow, England: Prentice Hall.

Burmann, C., \& Zeplin, S. (2005). Building brand commitment: A behavioural approach to internal brand management. Journal of Brand Management, 12(4), 279-300. https://doi.org/10.1057/palgrave.bm.2540223

Burmann, C., Zeplin, S., \& Riley, N. (2009). Key determinants of internal brand management success: An exploratory empirical analysis. Journal of Brand Management, 16(4), 264-284. doi: 10.1057/bm.2008.6; www.palgrave-journals.com $/ \mathrm{bm} /$

By, T. R. (2005). Organizational Change Management: A Critical Review. Journal of Change Management, 5(4), 369-380.

Celsi, R., \& Olson, J. C., (1988). The Role of Involvement in Attention and Comprehension Processes. Journal of
Consumer Research, 15(2), 210-224. https://doi.org/10.1086/209158

Chernatony, L. D., \& Harris, F. (2000). Developing corporate brands through considering internal and external stakeholders. Corporate Reputation Review, 3(3), 268-274.

https://doi.org/10.1057/palgrave.crr.1540119

Chin, W, W., \& Marcoulides, G. (1998). The Partial Least Squares Approach to Structural Equation Modeling. Advances in Hospitality and Leisure, 8(2), 295-335.

Chin, W. W., Peterson, S., \& Brown, S, P. (2008). Structural Equation Modeling in Marketing: Some Practical Reminders. The Journal of Marketing Theory and Practice, 16(4), 287-298. doi: 10.2753/MTP10696679160402

Churchill, G. A., \& Iacobucci, D. (2005). Marketing Research: Methodological Foundations. Mason, OH: Thomson/South-Western.

Day, G. S. (1994). The Capabilities of Market-Driven Organization. Journal of Marketing, 58(October), 37-52.

de Chernatony, L., \& McDonald, M. (1998). Creating powerful brands in consumer, service and industrial markets (2nd ed.). Oxford, UK: Butterworth Heinemann.

De Wit, B., \& Meyer, R. (2005) Strategy Synthesis: Resolving Strategy Paradoxes to Create Competitive Advantage (2nd ed). London, England: Thomson Learning.

Franzen, G., \& Bouwman, M. (2002). The mental world of brands- mind, memory and brand success. Brand Management, 9(6), 481-486.

Fugate, M., Kinicki, A. J., \& Ashforth, B. E. (2004). Employability: A Psycho-Social Construct, Its Dimensions, and Applications. Journal of Vocational Behavior, 65(1), 14-38. http://dx.doi.org/10.1016/j.jvb.2003.10.005

Gromark, J., \& Melin, F. (2010). From market orientation to brand orientation in the public sector. Journal of Marketing Management, 29, 1099-1123. http://dx.doi.org/10.1080/0267257X.2013.812134

Guthrie, M., \& Kim, H. S. (2009). The relationship between consumer involvement and brand perceptions of female cosmetic consumers. Journal of Brand Management, 17(2), 114-133. doi: 10.1057/bm.2008.28

Götz, O., Liehr-Gobbers, K., \& Krafft, M. (2009). Handbook of Partial Least Squares: Evaluation of Structural Equation Models Using the Partial Least Squares (PLS) Approach. Berlin, Heidelberg: Spinger.

Hair Jr, J. F., Hult, G. T., Ringle, C. M., \& Sarstedt, M. (2014). A Primer on Partial Least Squares Structural Equation Modeling (PLS-SEM). Thousand Oaks, CA: Sage Publications.

Henseler, J., Ringle, C. M., \& Sinkovics, R, R. (2009). The Use of Partial Least Squares Path Modeling in 
International Marketing: New Challenges to International Marketing. Advances in International Marketing, 20, 277-319. doi:10.1108/S14747979(2009)0000020014

Herman, D. (2001). The Guide for Brands Builders. Tel Aviv, Israel: Cherickover Publishing.

Heracleous, L., \& Barrett, M. (2001). Organizational change as discourse: communicative actions and deep structures in the context of information technology implementation. Academy of Management Journal, 44(4), 755-778. doi: 10.2307/3069414

Hoeffler, S., \& Keller, K. L. (2003). The marketing advantages of strong brands. Brand Management, 10(6), 421-445. https://doi.org/10.1057/palgrave.bm.2540139

Hult, G. T. M., \& Ferrell, O. C. (1997). Global organizational learning capacity in purchasing: Construct and measurement. Journal of Business Research, 40(2), 97-111. https://doi.org/10.1016/S01482963(96)00232-9

Hunt, S. D., \& Morgan, R. M. (1995). The comparative advantage theory of competition. Journal of Marketing, $59,1-15$.

Hunt, S. D., \& Madhavaram, S. (2012). Managerial action and resoruce-advantage theory: Conceptual frameworks emanating from a positive theory of competition. Journal of Business \& Industry Marketing, 27(7), 582591. doi: $10.1108 / 08858621211257356$

Jin, S. (2016). Examining the relationships among the brand equity dimensions, Asia Pacific Journal of Marketing and Logistics, 28(3), 464-480. http://dx.doi.org/10.1108/APJML-01-2015-0004

Lehr, J., \& Rice, R. (2002). Organizational measures as a form of knowledge management: A multitheoretic, communication-based exploration. Journal of the American Society for Information Science and Technology, 53(12), 1060-1073.

Https://doi.org/10.1002/asi. 10108

Luecke, R. (2003). Managing Change and Transition. Boston, MA: Harvard Business School Press.

Keller, K. L. (1993). Conceptualizing, measuring, and managing customer-based brand equity. Journal of Marketing, 57(1), 1-22.

Keller, K. L. (2003), Strategic Brand Management: Building, measuring and managing brand equit (2nd ed.). Englewood Cliffs, NJ: Prentice-Hall.

Keller, K. L. (2008), Strategic Brand Management (3rd ed.). Upper Saddle River, NJ: Prentice Hall.

Kitchen, P, J., Joanne, B., \& Tao, L. (2004). The Emergence of IMC: A Theoretical Perspective. Journal of Advertising Research, 44(1), 19-30. doi: $10.1017 / \mathrm{S} 0021849904040048$

Kotler, P., \& Pfoertsch, W. (2006). B2B Brand Management. New York, NY: Spinger Publisher
Lewin, K. (1951). Field theory in social science: selected theoretical papers. New York, NY: Harper \& Row.

Love, L., \& Singh, P. (2011). Workplace Branding: Leveraging Human Resources Management Practices for competitive Advantage Through Best Employer Surveys. Journal of Business Psychology, 26, 175-181. doi: 10.1007/s10869-011-9226-5

Leininger, M. M., \& McFarland, M. R. (2002) Transcultural nursing: Concepts, theories, research and practice (3rd ed.). New York, NY: McGraw-Hill.

Malhotra, N. (2007). Marketing Research: An applied approach. Upper Saddle River, NJ: Pearson Education.

Moran, J. W., \& Brightman, B., K. (2001). Leading organizational change. Career Development International, 6(2), 111-118.

Meaney, M., \& Pung, C. (2008). McKinsey global results: Creating organizational transformations. The McKinsey Quarterly, 7(3), 1-7. Retrieved October, 8, 2019 from http:/gsme.sharif.edu/ change/McKinsey\%20Global\% 20Survey\%20Results.pdf

Nelson, L. (2003). A case study in organizational change: implications for theory. The Learning Organization, 10(1), 18-30.

Nevis, E. C., Dibella, A. J., \& Gould, J. M. (1995). Understanding Organizations as Learning-Systems. Sloan Management Review, 36(2), 73-85.

Nunnally, J. C., \& Bernstein, I. H. (1994). The Assessment of Reliability. Psychometric Theory, 3, 248-292.

Park, W. C., \& Young, M. S. (1983). Types and Levels of Involvement and Brand Attitude, Advances in Consumer Research, 10, 320-324. http://acrwebsite.org/volumes/6133/volumes/v10/NA10

Papasolomou, I., \& Vrontis, D. (2006). Building corporate branding through internal marketing: the case of the UK retail bank industry. Journal of Product \& Brand Management, 15(1), 37-47. https://doi.org/10.1108/10610420610650864

Punjaisri, K., \& Wilson, A. (2007). The role of internal branding in the delivery of employee brand promise. Journal of Brand Management, 15(1), 57-70. https://doi.org/10.1057/palgrave.bm.2550110

Rajgopal, S., Venkatachalam, M., \& Kotha, S. (2002). Managerial actions, stock returns, and earnings: the case of business-to-business internet firms. Journal of Accounting Research, 40(2), 529-556.

Rieley, J. B., \& Clarkson, I. (2001). The impact of change on performance. Journal of Change Management, 2(2), 160-172.

Reichheld, F. F. (1996). Learning from Customer Defections. Harvard Business Review, 74(2), 56-69.

Riezebos, R. (2003). Brand management: A theoretical and practical approach. Harlow, UK: FT Prentice Hall. 
Ringle, C. M., Wende, S., \& Will, A. (2005). SmartPLS 2.0.M3. Hamburg, Germany: SmartPLS. Retrieved March 15, 2019, from http://www.smartpls.com

Schein, E. H., \& Bennis, W. G. (1965). Personal and organizational change through group methods: the laboratory approach. Hoboken, NJ: Wiley publishing.

Sekaran, U. (2010). Research Methods for Business: A Skill-Building Approach (4th ed.). Hoboken, NJ: John Wiley \& Sons.

Tajfel, H., \& Turner, J. C. (1986). The social identity theory of intergroup behavior. In S. Worchel \& L. W. Austin (Eds.), Psychology of intergroup relations. Chicago, IL: Nelson-Hall.

Urde, M. (1994). Brand Orientation - A Strategy for Survival. Journal of Consumer Marketing, 11(3), 18-32.

Urde, M. (1999). Brand Orientation: A Mindset for Building Brands into Strategic Resources. Journal of Marketing Management, 15(1), 117-133. doi: $10.1362 / 026725799784870504$

Urde, M. (2013). The corporate brand identity matrix. Journal of Brand Management, 20, 742-761. doi:10.1057/bm.2013.12
Yaniv, E., \& Farkas, F. (2005). The impact of personorganization fit on the corporate brand perception of employees and of customers. Journal of Change Management, 5(4), 447-461. https://doi.org/10.1080/14697010500372600

Xu, X., Payne, S. C., Horner, M. T., \& Alexander, A. L. (2012). Individual difference predictors of perceived organizational change fairness. Journal of Managerial Psychology, 31(2), 420-433.

Walinga, J. (2008). Toward a Theory of Change Readiness: The Roles of Appraisal, Focus, and Perceived Control. Journal of Applied Behavioral Science, 44(3), https://doi.org/10.1177/0021886308318967

Zaichkowsky, J. L. (1985). Measuring the involvement construct, Journal of Consumer Research, 12(3), 341352.

Zhang, J., Jiang, Y., Shabbir, R., \& Zhu, M. (2016). How brand orientation impacts B2B service brand equity? An empirical study among Chinese firms. Journal of Business \& Industrial Marketing, 31(1), 83-98. http://dx.doi.org/10.1108/JBIM-02-2014-0041 